\title{
Potential and safety tests of egg drop syndrome candidate vaccine from Medan isolate, Indonesia
}

\author{
Gusti Ayu Yuniati Kencana ${ }^{1}$, Nyoman Suartha², I Made Kardena ${ }^{3}$, Gusti Ayu Mayani Kristina Dewi ${ }^{4}$, Arini \\ Nurhandayani ${ }^{5}$, Syamsidar ${ }^{5}$ and Kadek Karang Agustina ${ }^{6}$
}

1. Department of Virology, Faculty of Veterinary Medicine, Udayana University, Denpasar, Indonesia; 2. Department of Internal Medicine, Faculty of Veterinary Medicine, Udayana University, Denpasar, Indonesia; 3. Department of Pathology,

Faculty of Veterinary Medicine, Udayana University, Denpasar, Indonesia; 4. Department of Poultry Science, Faculty Animal Husbandry, Udayana University, Denpasar, Indonesia; 5. PT. Sanbio Laboratories, Bogor, Jawa Barat, Indonesia; 6. Department of Public Health, Faculty of Veterinary Medicine, Udayana University, Denpasar, Indonesia. Corresponding author: Gusti Ayu Yuniati Kencana, e-mail: yuniati_kencana@unud.ac.id

Co-authors: NS: nyoman_suartha@unud.ac.id, IMK: imadekardena@unud.ac.id, GAMKD: kristinadewi@unud.ac.id, AN: arininur78@yahoo.co.id, S: syamsidar23@ymail.com, KKA: k.agustina@unud.ac.id

Received: 03-05-2018, Accepted: 11-10-2018, Published online: 29-11-2018

doi: 10.14202/vetworld.2018.1637-1640 How to cite this article: Kencana GAY, Suartha N, Kardena IM, Dewi GAMK, Nurhandayani A, Syamsidar, Agustina KK (2018) Potential and safety tests of egg drop syndrome candidate vaccine from Medan isolate, Indonesia, Veterinary World, 11(11): 1637-1640.

\begin{abstract}
Aim: The study was aimed to prepare and examine the potential and safety concerns of egg drop syndrome (EDS) vaccine candidate seed. The potential and safety trials of EDS Medan isolate vaccine need to be done before commercial scale of EDS vaccines are made.

Materials and Methods: The safety test of EDS candidate vaccine was tested on 4-week-old specified pathogen-free chickens in an experimentally isolated enclosure.

Results: The result of the safety test obtained $2^{7.3}$ hemagglutination inhibition (HI) unit of geometric mean titer antibody post-vaccination. However, the potency test of the EDS candidate vaccine was conducted on 17-week-old laying hens. Test results of the EDS potency vaccine in layer obtained antibody titer increased in every week of blood taking with average titer of antibody: Before vaccinated was $2^{2.9} \mathrm{HI}$ unit, 1 week after vaccination was $2^{3.7} \mathrm{HI}$ unit, 2 weeks post-vaccination was $2^{5} \mathrm{HI}$ unit, and 3 weeks after vaccination was $2^{7.3} \mathrm{HI}$ units. In contrast, decreasing trend was observed in control group (unvaccinated chicken).
\end{abstract}

Conclusion: Serologically, the seed vaccine of EDS virus isolates from Medan was able to produce protective antibody titers starting in the $2^{\text {nd }}$ and $3^{\text {rd }}$ weeks post-vaccination.

Keywords: hemagglutination, inhibition test, Medan isolate, safety and potential test, seed of egg drop syndrome vaccine.

\section{Introduction}

Egg drop syndrome (EDS) is a disease caused by the duck adenovirus belonging to family Adenoviridae and genus of Atadenovirus. The virus was $1^{\text {st }}$ time discovered in 1976 in the Netherlands [1]. Therefore, it was called EDS - 1976 and later on abbreviated to EDS-76 [2]. Adenovirus particles are icosahedral in structure with 70-90 nm in diameter [3]. Virus particles are composed of 252 capsomers of triangular form. The genome of EDS 1976 is linear and composed of double-stranded deoxyribonucleic acid (DNA). Adenovirus is reported resistant to $\mathrm{pH}$ 3-9 but can be inactivated with 1:1000 formalin. Some strains of adenovirus can survive at $60-70^{\circ} \mathrm{C}$ for $30 \mathrm{~min}$. The $\mathrm{F} 1$ strain can survive up to $56^{\circ} \mathrm{C}$ for $18 \mathrm{~h}$. In Group I adenovirus, only F1 strain can agglutinate the red blood cells [4,5].

Copyright: Kencana, et al. Open Access. This article is distributed under the terms of the Creative Commons Attribution 4.0 International License (http://creativecommons.org/licenses/ by/4.0/), which permits unrestricted use, distribution, and reproduction in any medium, provided you give appropriate credit to the original author(s) and the source, provide a link to the Creative Commons license, and indicate if changes were made. The Creative Commons Public Domain Dedication waiver (http:// creativecommons.org/publicdomain/zero/1.0/) applies to the data made available in this article, unless otherwise stated.
EDS is a viral disease of layer birds, found mainly during peak production causing high economic losses [6,7]. EDS mainly attacks layers that are in the reproductive ages of 25-26 weeks [8]. Ducks and geese are reservoirs of the EDS virus and are the sources of virus transmissions through contaminated water [9]. The EDS disease is characterized by specific symptoms of decrease in the quality and quantity of eggs during peak production. Low egg quality is characterized by small size egg with mushy eggshell which can be easily broken (Figure-1) [10,11], which leads farmers to huge economic losses. EDS virus initially infected breeding farms and later on spread to other farms through infected eggs [12]. Adenovirus has become endemic in various parts of the world including Indonesia. It is a strategic infectious disease that must be eradicated [13]. EDS can be prevented by vaccination of layer before laying. In Indonesia, EDS vaccination has been adopted by several farmers, but EDS outbreak is still reported from layer birds [11].

For this purpose, isolation and characterization of EDS virus from field isolate are required. Isolate Medan used as seed vaccine taken from commercial poultry farms in Medan that shows the clinical symptoms of decreased egg production with a flabby 


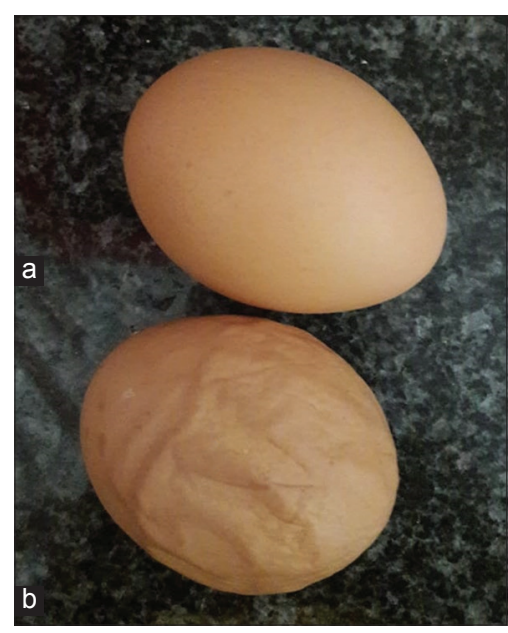

Figure-1: (a) Normal egg and (b) Egg drop syndrome egg abnormalities (personal archive).

shell [11]. With such an assumption, the vaccine made from local seed virus would be more appropriated if it used to prevent EDS epidemic in Indonesia. This study was carried out to test the potential and safety of vaccines derived from local isolates.

\section{Materials and Methods}

\section{Ethical approval}

This research was accepted in the Ethical Commission for the Use of Animals in Research and Education of the Faculty of Veterinary Medicine, Udayana University, Indonesia with Ref. No. 297a/ KE-PH/VII/2017.

\section{EDS vaccine candidate}

EDS isolates came from the city of Medan (Indonesia), which was taken from the field case of laying hens with EDS clinical symptoms. Samples of isolates were taken from the uterus and oviducts, isolated in 11-day-old spotted duck eggs. Inoculated for 3 days and then harvested, the allantoic liquid was tested by hemagglutination (HA) and polymerase chain reaction tests. The HA test results of the viral titers were $2^{12} \mathrm{HA}$ units, and DNA amplification was $500 \mathrm{bp}$ [11]. The EDS isolates of Medan were subsequently inactivated, emulsified, and used as EDS vaccine seeds. Safety test for EDS vaccine candidate was performed on specified pathogen-free (SPF) chickens in the experimental cage at PT. Sanbio Laboratories, while the potential test was done on commercial layer at the Faculty of Animal Husbandry, Udayana University.

The safety test of the EDS vaccine candidate was performed in $10 \mathrm{SPF}$ chickens of 4-week-old vaccinated by injecting one dose in thigh muscles with EDS vaccine candidate. 10 other SPF chickens were used as controls. The content of EDS virus for vaccine candidates was made by conducting double-fold serial dilutions starting from titers $2^{1}$ to $2^{20}$ to be formulated into $2^{15} \mathrm{HA}$ units as requirements for candidate vaccines based on Indonesian Medicine Federation standards. The $2^{15} \mathrm{HA}$ units were calculated by the
HA test. The vaccine manufacturing process begins with adding $70 \%$ of the oil phase (adjuvant) to inactivated EDS virus isolates into the mixing tank, followed by the addition of $30 \%$ water phase, emulsified to homogeneous. The volume of vaccine candidates injected into SPF chickens was $0.5 \mathrm{ml}$ containing $2^{15}$ HA units, while the control was injected with $0.5 \mathrm{ml}$ phosphate-buffered saline. Observation of the safety test of the EDS vaccine candidate was conducted for 2 weeks. Seed vaccine was said to be eligible if all the treated and control groups of the chickens remained alive and well during the study period.

The potency test of EDS vaccine candidate was done at the Faculty of Animal Husbandry, Udayana University. A total of 50 layers were used for the research purpose. Vaccination was performed on 18 -week-old layers with one dose $(0.5 \mathrm{ml})$ of intramuscular vaccine in thigh muscles. Blood sampling for serum was performed for 4 times: The $1^{\text {st }}$ time before vaccination and later on 3 times was performed every week after post-vaccination up to the $4^{\text {th }}$ week. Every day, the clinical symptoms are observed, and at the end of the study, all chickens were killed to observe their gross pathological changes.

The antibody titers were tested by HA reaction and inhibition-based serological test (HA/hemagglutination inhibition [HI]) [14-16]. These tests were performed at Virology Laboratory, Faculty of Veterinary Medicine, Udayana University. The antibody titers obtained were statistically analyzed using ANOVA test [17].

\section{Results and Discussion}

The result of the research of Medan isolate showed that the seeds of EDS vaccine used in Medan isolate did not cause clinical symptoms in the chickens. Thus, it can be concluded that the EDS vaccine seed isolate Medan is safe to be used. Serologic test results with HA resistance from vaccinated SPF serum showed a mean of the titer of geometric mean titer antibody of $2^{7.3}$ with the lowest titer of $2^{5} \mathrm{HI}$ unit, while the highest titer was $2^{10} \mathrm{HI}$ unit. Unlike the antibody titer of non-vaccinated control chicken, the HA test results showed zero titer (Table-1). This proves that the Medan EDS virus isolates are safe to be used as EDS vaccine seeds.

Potency test of EDS vaccine seeds in commercial laying chickens vaccinated at 17 weeks, produced an antibody titer that increased in every week post-vaccination. Serologically, the EDS vaccine candidate of Medan isolates is eligible for EDS vaccine because it was able to produce antibody titer of $2^{7.3}$ HI units in layer vaccinated at 17 weeks (Figure-2). The antibody titer result was protective antibody titer because it was $>2^{4} \mathrm{HI}$ units. Bidin et al. [18] reported on EDS-vaccinated chickens at 18 weeks of age to produce antibody titers of $16-256 \mathrm{HI}$ units or $2^{4}-2^{8} \mathrm{HI}$ units in $96.7 \%$ of the samples. The increase of EDS antibody titer in this study is also similar to the results 
Table-1: Antibody titer of SPF chickens post-vaccination of EDS seed vaccine.

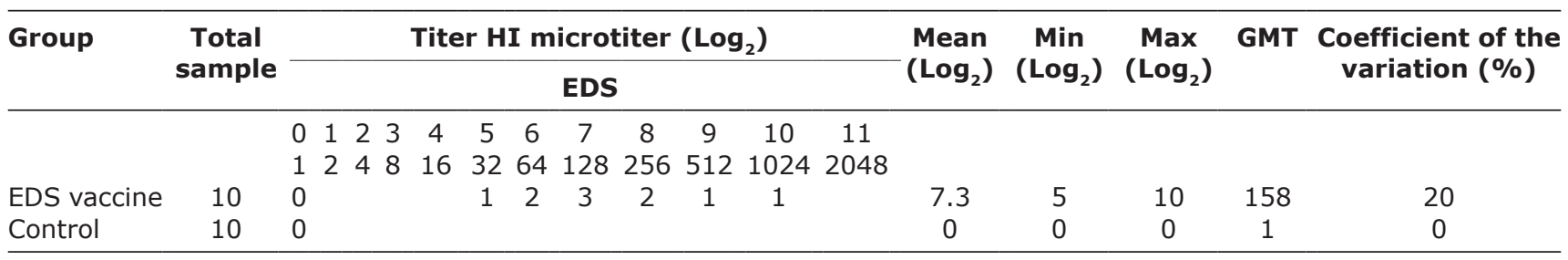

$\mathrm{SPF}=$ Specific pathogen free, EDS=Egg drop syndrome, GMT=Geometric mean titter, $\mathrm{HI}=$ Hemagglutination inhibition

Table-2: Effects of the vaccination on antibody against EDS in the commercial laying chickens.

\begin{tabular}{|c|c|c|c|c|c|}
\hline Source & Type III sum of squares & df & Mean square & $\mathbf{F}$ & Significant \\
\hline \multicolumn{6}{|l|}{ Intercept } \\
\hline Hypothesis & 1994.425 & 1 & 1994.425 & 434.604 & 0.000 \\
\hline Error & 220.275 & 48 & $4.589^{a}$ & & \\
\hline \multicolumn{6}{|l|}{ Treatment } \\
\hline Hypothesis & 93.845 & 1 & 93.845 & 20.450 & 0.000 \\
\hline Error & 220.275 & 48 & $4.589^{a}$ & & \\
\hline \multicolumn{6}{|c|}{ Treatment* repetition } \\
\hline Hypothesis & 220.275 & 48 & 4.589 & 1.457 & 0.047 \\
\hline Error & 453.575 & 144 & $3.150^{\mathrm{b}}$ & & \\
\hline \multicolumn{6}{|l|}{ Time } \\
\hline Hypothesis & 59.265 & 3 & 19.755 & 6.272 & 0.000 \\
\hline Error & 453.575 & 144 & $3.150^{\mathrm{b}}$ & & \\
\hline \multicolumn{6}{|c|}{ Treatment*time } \\
\hline Hypothesis & 164.705 & 3 & 54.902 & 17.430 & 0.000 \\
\hline Error & 453.575 & 144 & $3.150^{\mathrm{b}}$ & & \\
\hline
\end{tabular}

Dependent variable: Antibody titer of laying chickens post-vaccination of EDS seed vaccine. EDS=Egg drop syndrome

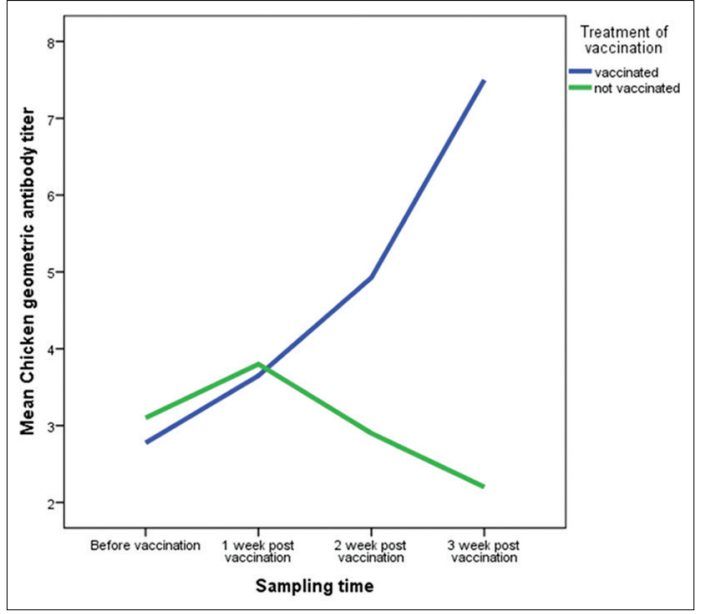

Figure-2: The increased titer of egg drop syndrome antibody in laying hens before and after vaccination.

of vaccination with the commercial vaccine Shanvac ND-IB-EDS in commercial laying hen farms that were capable to trigger antibody titer of $2^{7} \mathrm{HI}$ units for 3-week post-vaccination period [19].

The result of analysis variance showed that vaccine administration had a significant effect on chicken antibody titer $(p<0.05)$. The time of blood taking had a significant effect on chicken antibody titer $(\mathrm{p}<0.05)$. There was also a significant association between timing of vaccination and serum collection (Table-2). While the antibody titer in the control group of chicken decreased during maintenance period. This may be due to the presence of maternal antibodies due to vaccination in the mother $[20,21]$ and can also result from non-specific infections that reduce general immunity [22].

Clinical observation results in post-vaccinated chickens with EDS isolate Medan did not experience any clinical sign. The chickens that got vaccination by EDS isolates Medan vaccine candidate produced eggs with normal in shape, size, and production. Unlike the infected chickens, EDS caused low-quality eggs such as thin eggshells and around $10-30 \%$ decline in egg production [23]. In experimental infections, respiratory distress occurs in the 3-4 days post-infection period with a $10-40 \%$ decrease in production, but no death was observed [9].

\section{Conclusion}

Based on the results of the experimental test of Medan isolate EDS candidate vaccine in SPF chickens or in layers, it can be concluded that EDS vaccine is safe to be used as a vaccine against EDS. Seeds of EDS vaccine Medan isolates may trigger protective antibody formation from 2-week post-vaccination with antibody titers of $2^{5} \mathrm{HI}$ units and $2^{7.3} \mathrm{HI}$ units for 3-weeks post-vaccination. Further, research on EDS Medan vaccine isolates is needed to be used as EDS vaccine and its effect on production in commercial chicken farms. The challenge infection by virulent EDS virus post-vaccination is not done in the present study, but we wish to do it in the future.

\section{Authors' Contributions}

GAYK: Plan, conduct research, and write a script. NS: Perform serological tests and test vaccine 
potential. IMK: Potential test, data analysis, and write a script, GAMKD: Maintain and supervise experimental chickens. AN: Virus isolation and vaccine safety test. S: Virus isolation and vaccine safety test. KKA: Data analysis and write a script. All authors read and approved the final manuscript.

\section{Acknowledgments}

We would like to thank Rector of Udayana University, Indonesia and PT. Sanbio Laboratories, Indonesia for fund and support of this research with Contract No. 673-30/UN14.4.A/LT/2017.

\section{Competing Interests} interests.

The authors declare that they have no competing

\section{References}

1. Rasool, M.H., Rahman, S.U. and Mansoor, M.K. (2005) Isolation of egg drop syndrome virus and its molecular characterization using sodium dodecyl sulphate polyacrylamide gel electrophoresis. Pak. Vet. J., 25(4): 155-158.

2. Banani, M., Sehat, M., Pourbakhsh, S.A., Haerian, B. and Shahsavandi, S. (2007) Application of polymerase chain reaction in detection of egg drop syndrome (EDS) virus. Arch. Razi Inst., 62(3): 127-133.

3. Martin, C.S. (2012) Latest insights on adenovirus structure and assembly. Viruses, 4(5): 847-877.

4. McFerran, J.B. and Smyth, J.A. (2000) Avian adenovirus. Rev. Sci. Tech. Off. Int. Epiz., 19(2): 589-601.

5. Center for Food Security and Public Health (CFSPH). (2018) Vaccines: Egg Drop Syndrome. Institute for International Cooperation in Animal Biology, Iowa State University, Ames, IA.

6. McFerran, J.B. and Adair, B.M. (2003) Egg drop syndrome. In: Saif, Y.M., Barnes, H.J., Glisson, J.R., Fadly, A.M., McDougald, L.R. and Swayne, D.E. editors. Diseases of Poultry. $11^{\text {th }}$ ed. Iowa State Press, Ames, Iowa. p227-237.

7. Begum, J.A., Chowdhury, E.H., Parvin, R., Matin, M.A., Giasuddin, M., Bari, A.S.M. and Islam, M.R. (2013) Detection of egg drop syndrome virus by polymerase chain reaction. Int. J. Livestock Res., 3(2): 112-116.

8. Dinev, I. (2012) Leg weakness pathology in broiler chickens. J. Poult. Sci., 49(2): 63-67.

9. Center for Food Security and Public Health (CFSPH). (2006) Egg Drop Syndrome. College of Veterinary Medicine, Iowa State University, Ames, IA.

10. Alam, J., Al-Mamun, M., Samad, M.A., Ullah, M.R., Giasuddin, M. and Taimur, M.J.F. (2009) Outbreak of egg drop syndrome in Bangladesh. Int. J. Biol., 1(1): 56-64.

11. Kencana, G.A.Y., Suartha, I.N., Nurhandayani,A. and Syamsidar.
(2017) The characteristic of egg drop syndrome virus of Medan isolate. J. Vet. Med. Anim. Sci., 1(1): 15-19.

12. Su, J., Li, S., Hu, X., Yu, X., Wang, Y., Liu, P., Lu, X., Zhang, G., Hu, X., Liu, D., Li, X., Su, W., Lu, H., Mok, N.S., Wang, P., Wang, M., Tian, K. and Gao, G.F. (2011) Duck egg-drop syndrome caused by BYD virus, a new tembusu-related flavivirus. PLoS One, 6(3): e18106.

13. Kementerian Pertanian (Kementan). (2013) Keputusan Menteri Pertanian No.4026/Kpts/OT.140/4/2013. Tentang Penetapan Jenis Penyakit Hewan Menular Strategis, Jakarta.

14. Office International des Epizooties (OIE). (2006) Egg Drop Syndrome. Animal Disease Factsheets, The Center for Food Security and Public Health. Iowa State University, Ames, IA, USA. p1-3.

15. Mahardika, G.N., Adi, A.A.A., Besung, N.K., Dharmawan, N.S., Kencana, G.A.Y., Rompis, A.L.T., Sampurna, P., Setiasih, L.E., Suardana, W., Suardana, I.B.K., Suarjana, G.K., Suartha, N., Suartini, G.A.A., Suwiti, N.K. and Utama, I.H. (2018) Surveillance of avian influenza virus of H5N1 subtype in backyard animals and its introduction in Bali, Indonesia. Pak. Vet. J., 38(1): 7-12.

16. Suartha, I.N., Suartini, G.A.A., Wirata, I.W., Dewi, N.M.A., Putra, G.N.N., Kencana, G.A.Y. and Mahardika, G.N. (2018) Intranasal administration of inactivated avian influenza virus of $\mathrm{H} 5 \mathrm{~N} 1$ subtype vaccine-induced systemic immune response in chicken and mice. Vet. World, 11(2): 221-226.

17. Biller-Takahashi, J.D., Montassier, H.J., Takahashi, L.S. and Urbinati, E.C. (2012) Proposed method for agglutinating antibody titer analysis and its use as indicator of acquired immunity in pacu, Piaractus mesopotamicus. Braz. J. Biol., 74(1): 238-242.

18. Bidin, Z., Lojkic, I., Mikec, M. and Pokric, B. (2007) Naturally occurring egg drop syndrome infection in Turkeys. Acta Vet. Brno, 76(3): 415-421.

19. Kencana, G.A.Y., Suartha, I.N., Nainggolan, D.R.B. and Tobing, A.S.L. (2017) Respons imun ayam petelur pascavaksinasi newcastle disease dan egg drop syndrome. J. Sain Vet., 35(1): 81-90.

20. Faulkner, O.B., Estevez, C., Yu, Q. and Suarez, D.L. (2013) Passive antibody transfer in chickens to model maternal antibody after avian influenza vaccination. Vet. Immunol. Immunopathol., 152(3-4): 341-347.

21. Besseboua, O., Ayad, A. and Benbarek, H. (2015) Determination of the optimal time of vaccination against infectious bursal disease virus (gumboro) in Algeria. Onderstepoort J. Vet. Res. 82(1): 887.

22. Alexander, DJ., Aldous, E.W. and Fuller, C.M. (2012) The long view: A selective review of 40 years of Newcastle disease research. Avian Pathol., 41(4): 329-335.

23. Salihu, A.E., Joannis, T.M., Onwuliri, F.C., Masdooq, A.A., Muazu, A., Haruna, G., Ibu, J.O. and Ngbede, J. (2010) Serological evidence of egg drop syndrome'1976 (EDS'76) in free-range chickens at chicken market sites in Jos, Nigeria. Turk. J. Vet. Anim. Sci., 34(4): 403-406. 